\title{
The Indonesian Society of Endocrinology's Summary Article of Diabetes Mellitus National Clinical Practice Guidelines
}

\author{
Ahmad Rudianto ${ }^{1}$, Pradana Soewondo², Sarwono Waspadji², Em Yunir², Dyah Purnamasari² \\ on behalf of the Indonesian Society of Endocrinologists (ISE) \\ ${ }^{1}$ Department of Internal Medicine, Faculty of Medicine, Brawijaya University, Malang, Indonesia \\ ${ }^{2}$ Division of Endocrinology, Department of Internal Medicine, \\ Faculty of Medicine, University of Indonesia, Cipto Mangunkusumo Hospital, Jakarta, Indonesia
}

\begin{abstract}
Introduction
Various epidemiological studies indicate increased incidence and prevalence rates of type 2 Diabetes Mellitus (DM) worldwide. Research in various areas in Indonesia in the 1980s indicated that the distribution of type 2 diabetes prevalence was $6.1 \%$ obtained in Manado. A study in Jakarta, the capital city of Indonesia, reported a steep rise in the prevalence of DM from $1.7 \%$ in 1982, 5.7\% in 1993 to $12.8 \%$ in 2001.
\end{abstract}

The Central Bureau of Statistics Indonesia (2003) estimated that the number of adult population over 20 years old is approximately 133 million. Based on the prevalence of DM in urban $(14.7 \%)$ and rural $(7.2 \%)$ areas, it was predicted that by the year 2003, there shall be 8.2 million and 5.5 million people with DM in urban and rural areas, respectively. A study by the Health Research Association of the Ministry of Health in 2007, showed that the prevalence of DM in urban areas in Indonesia among 15 years old and above was $5.7 \%$. The lowest and highest prevalence rates were $1.7 \%$ in Papua and $11.1 \%$ in North Maluku and West Kalimantan. The prevalence of impaired glucose tolerance (IGT) ranged from $4.0 \%$ in Jambi Province to $21.8 \%$ in West Papua Province.

Diabetes mellitus is a chronic disease. In addition to doctors, nurses, nutritionists and other health personnel, the role of patients and family members is very important. Education of patients and their families will provide further understanding about the course of the disease, prevention, complications, and likewise increase their participation in the management of DM.

To provide proper management and reduce the incidence of chronic complications, a standard guideline for managing DM is needed. Completion and periodic revision of standards of care should be ongoing and tailored to the latest scientific advances, to obtain maximum benefits for persons with diabetes.
This guideline contains the fourth revised consensus of "The Management and Prevention of DM in Indonesia." The latest revision was based on the agreement of diabetes experts in Indonesia which was initiated by the PB Perkeni (Indonesian Society of Endocrinology, ISE) meeting in Jakarta. The consensus has already been revised several times, from 1998, 2002, 2006 to 2010.

\section{Definition}

According to the American Diabetes Association (ADA) 2010, diabetes mellitus is a group of metabolic diseases with characteristic hyperglycemia that occurs because of abnormalities of insulin secretion, insulin resistance or both.

\section{Classification}

The classification of DM can be seen in Table 1.

\begin{tabular}{|c|c|}
\hline Type 1 & $\begin{array}{l}\text { Beta cell destruction, usually leading to absolute insulin d } \\
\text { eficiency } \\
\text { Autoimmune } \\
\text { ldiopathic }\end{array}$ \\
\hline Type 2 & $\begin{array}{l}\text { Varied, ranging from dominant insulin resistance } \\
\text { accompanied by relative insulin deficiency to } \\
\text { predominantly insulin secretory defect with insulin } \\
\text { resistance }\end{array}$ \\
\hline $\begin{array}{l}\text { Other } \\
\text { types }\end{array}$ & $\begin{array}{l}\text { Genetic defect of beta cell function } \\
\text { Genetic defect of insulin } \\
\text { Exocrine pancreatic disease } \\
\text { Endocrinopathy } \\
\text { Because the drug or chemical substance } \\
\text { Infection } \\
\text { Rare immunological causes } \\
\text { Other genetic syndromes associated with DM }\end{array}$ \\
\hline $\begin{array}{l}\text { Gestational } \\
\text { DM }\end{array}$ & $\begin{array}{l}\text { Any degree of glucose intolerance with onset or first } \\
\text { recognition during pregnancy }\end{array}$ \\
\hline
\end{tabular}

\section{Diagnosis}

Diabetes mellitus is diagnosed by venous blood glucose examination, which uses an enzymatic method. For monitoring the adequacy of treatment, capillary blood glucose (CBG) examination with a glucometer can be used.
ISSN 0857-1074

Copyright $(\subset 2011$ by the JAFES

Received February 25, 2011. Accepted May 3, 2011.
Corresponding author: Dyah Purnamasari, SpPD

Division of Endocrinology, Department of Internal Medicine,

Faculty of Medicine, University of Indonesia, Cipto Mangunkusumo Hospital,

Jakarta, Indonesia

E-mail:dyah_p_irawan@yahoo.com 


\section{Diagnosis of DM}

If there are classic symptoms (polyuria, polyphagia, polydipsia and weight loss with unknown etiology), then random blood glucose $\geq 200 \mathrm{mg} / \mathrm{dL}$ or fasting plasma glucose $\geq 126 \mathrm{mg} / \mathrm{dL}$ are sufficient to diagnose diabetes. If there are no classic symptoms, we need two abnormal blood glucose level results.

Although the oral glucose tolerance test (OGTT) by $75 \mathrm{~g}$ glucose load is more sensitive and specific than fasting plasma glucose checks, it has some limitations. It is difficult to perform repeatedly and is very rarely done in practice. If the OGTT results do not meet the diagnosis of diabetes, depending on the results obtained, it can be classified into either impaired glucose tolerance (IGT), impaired fasting glucose (IFG) or the combination of both (IGT-IFG).

1. IGT: IGT is established when the 2 hour post loading plasma glucose ranges from 140 to 199 $\mathrm{mg} / \mathrm{dL}$ (7.8 to $11.0 \mathrm{mmol} / \mathrm{L}$ ) and the fasting plasma glucose is $<100 \mathrm{mg} / \mathrm{dL}(5.6 \mathrm{mmol} / \mathrm{L})$.

2. IFG: IFG is established when the 2 hour post loading plasma glucose is $<140 \mathrm{mg} / \mathrm{dL}$ (7.8 $\mathrm{mmol} / \mathrm{L}$ ) and the fasting plasma glucose ranges from 100 to $126 \mathrm{mg} / \mathrm{dL}$ (5.6 to $6.9 \mathrm{mmol} / \mathrm{L}$ ).

3. IGT-IFG: IGT-IFG is established when the 2 hour post loading plasma glucose ranges from 140 to $199 \mathrm{mg} / \mathrm{dL}$ (7.8 to $11.0 \mathrm{mmol} / \mathrm{L}$ ) and the fasting plasma glucose ranges from 100 to $126 \mathrm{mg} / \mathrm{dL}$ (5.6 to $6.9 \mathrm{mmol} / \mathrm{L})$.

Criteria for diagnosis of DM can be seen in Table 2.

Table 2. Criteria for diagnosis of DM

1. Classic symptoms of DM + random blood glucose $\geq 200$ $\mathrm{mg} / \mathrm{dL}(11.1 \mathrm{mmol} / \mathrm{L})$

Random blood glucose is the result of examination at any time in a day regardless of the time of the last meal.

2. Classic symptoms of DM Or

Fasting blood glucose level $\geq 126 \mathrm{mg} / \mathrm{dL}(7.0 \mathrm{mmol} / \mathrm{L})$ Fasting is defined as the condition when patients do not obtain extra calories for at least 8 hours

$$
\text { Or }
$$

3. The 2 hours post loading plasma glucose $\geq 200 \mathrm{mg} / \mathrm{dL}$ (11.1 $\mathrm{mmol} / \mathrm{L}$ )

OGTT is performed according to WHO standard, using $75 \mathrm{~g}$ anhydrous glucose load which is dissolved into the water

ADA 2010 had also recommended using A1C $\geq 6.5 \%$ as part of diabetes diagnostic criteria. The diagnostic test should be performed using a method certified by the National Glycohemoglobin Standardization Program (NGSP) and standardized or traceable to the Diabetes Control and Complications Trial (DCCT) reference assay.

The preparation of OGTT is based on WHO guidelines (1994) as described below:

- Three days before the examination, the subject may keep his daily eating habits (with enough carbohydrates) and usual physical activities

- $\quad$ Fasting for at least 8 hours (starting the night) before the examination. Plain water may be allowed
- Collect blood sample for fasting blood glucose examination

- Give 75 grams of anhydrous glucose (adults), or $1.75 \mathrm{~g} / \mathrm{kg}$ (children), dissolved in $250 \mathrm{~mL}$ of water and drink within 5 minutes

- Fasting for 2 hours after ingestion of glucose load.

- Collect blood sample for 2 hour post loading blood glucose examination

- During the OGTT procedure, the subject must remain at rest and must not smoke

\section{Screening}

Screening is conducted on those who have diabetes risks, but do not show any symptoms of DM. Screening seeks to capture undiagnosed DM or prediabetes so it can be managed earlier and more appropriately.

Mass screening is not recommended considering the costs, which are generally not followed by action plan for those who were found to have abnormal results.

Standard values of random blood glucose and fasting blood glucose for screening and diagnosis of DM can be seen in Table 3.

Table 3. Standard values of random blood glucose and fasting blood glucose for screening and diagnosis of $\mathrm{DM}(\mathrm{mg} / \mathrm{dL})$

\begin{tabular}{|c|c|c|c|c|}
\hline & & Non DM & Uncertain DM & DM \\
\hline $\begin{array}{l}\text { Random blood } \\
\text { glucose level } \\
\text { (mg/dL) }\end{array}$ & $\begin{array}{l}\text { Venous } \\
\text { plasma }\end{array}$ & $<100$ & $100-199$ & $\geq 200$ \\
\hline $\begin{array}{l}\text { Fasting blood } \\
\text { glucose level } \\
\text { (mg/dL) }\end{array}$ & $\begin{array}{l}\text { Venous } \\
\text { plasma }\end{array}$ & $<100$ & $100-125$ & $\geq 126$ \\
\hline \multicolumn{5}{|c|}{$\begin{array}{l}\text { Notes: For high-risk groups which show no abnormal results, the test } \\
\text { should be done every year. For those aged }>45 \text { years without other risk } \\
\text { factors, screening can be done every } 3 \text { years. The diagnostic procedure } \\
\text { for DM can be seen in Figure } 1 \text {. }\end{array}$} \\
\hline
\end{tabular}

\section{References}

1. American Association of Clinical Endocrinologists (AACE) Diabetes Mellitus Clinical Practice Guidelines Task Force. AACE medical guidelines for clinical practice for the management of diabetes mellitus. Endo Pract. 2007;13(Supl 1)

2. American Diabetes Association. Position statement: Standards of Medical Care in Diabetes 2010. Diab Care. 2010;33(Suppl.1)

3. American Diabetes Association. Gestational diabetes mellitus. Diab Care. January 2004. 27(Supl1):s88-s90

4. Cockram CS. The epidemiology of diabetes mellitus in the AsiaPacific region. HKMJ 2000;6:43-52

5. IDF Clinical Guidelines Task Force. Global guideline for type 2 diabetes. Brussels: International Diabetes Federation, 2005.

6. King H, Aubert RE, Herman WH. Global burden of diabetes, 19952025: Prevalence, numerical estimates, and projections. Diab Care. 1998; 21:1414-31

7. Mihardja L, Delima, Manz HS, Ghani L, Soegondo S. Prevalence and determinants of diabetes mellitus and impaired glucose tolerance in Indonesia (a part of basic health research / Riskesdas). Acta Med Indones. 2009 Oct;41(4):169-74.

8. Pramono LA, Setiati S, Soewondo P, Subekti I, Adisasmita A, Kodim $\mathrm{N}$, Sutrisna B. Prevalence and predictors of undiagnosed diabetes mellitus in Indonesia. Acta Med Indones. 2010 Oct;42(4):216-23.

9. Rahajeng E, Kusumawardani N, Yunir E, Oemardi M, Subekti I. Incidence rate of type 2 diabetes mellitus in population with impaired 


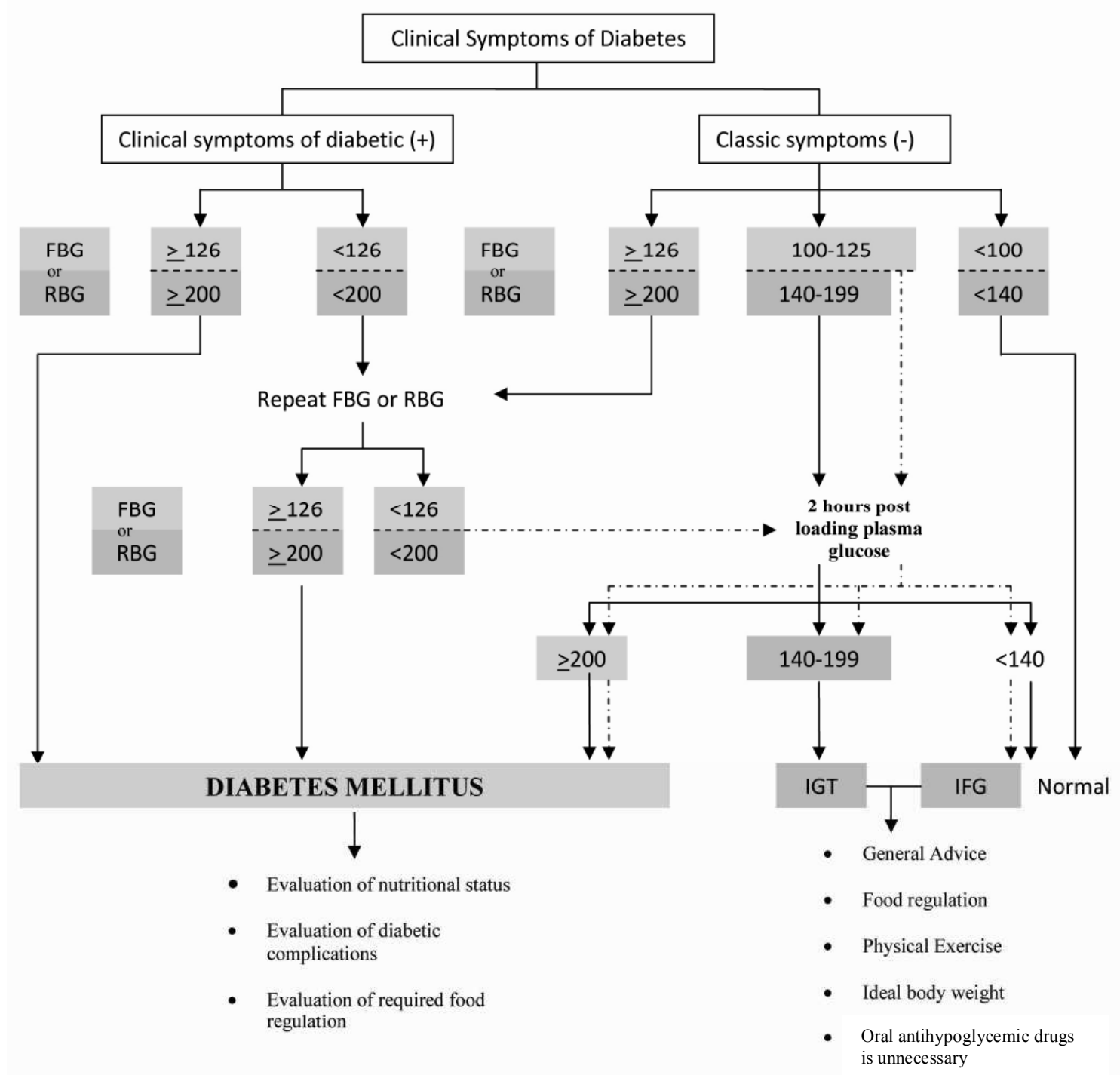

FBG: Fasting Blood Glucose

RBG: Random Blood Glucose

IFG: Impaired Fasting Glucose

IGT: Impaired Glucose Tolerance

Figure 1

glucose tolerant (IGT) and its determinant factors in Depok, West Java, Indonesia. JAFES. 2005. 23(1):S45

10. Subekti I, Yunir E, Soebardi S, Oemardi M. Epidemiologic study on the prevalence of glucose tolerance in Depok (West Java) population. JAFES. 2005. 23(1):S47

11. Sutanegara D, Darmono, Budhiarta AAG. The epidemiology and management of diabetes mellitus in Indonesia. Diab Research and Clin Pract. 2000. 50(2): S9-S16

12. The National Institute of Health Research and Development, Minisry of Health, Republic of Indonesia. Report on result of National Basic Health research (RISKESDAS) 2007.

13. The Central Bureau of Statistics Indonesia. 2003

14. The Indonesian Society of Endocrinology. Consensus on Diabetes Mellitus Management in Indonesia. Editor : Soegondo S, Soewondo P, Subekti I, et al. The Indonesian Society of Endocrinology. Jakarta 1998.
15. The Indonesian Society of Endocrinology. Consensus on Diabetes Mellitus Management in Indonesia. Editor : Soegondo S, Soewondo P, Subekti I, et al. The Indonesian Society of Endocrinology. Jakarta 2002.

16. The Indonesian Society of Endocrinology. Consensus on Diabetes Mellitus Management in Indonesia. Editor : Soegondo S, Soewondo P, Subekti I, et al. The Indonesian Society of Endocrinology. Jakarta 2006.

17. Waspadji S, Ranakusuma AB, Suyono S, Supartondo S, Sukaton U. Diabetes mellitus in an urban population in Jakarta, Indonesia. Tohoku J Exp Med. 1983 Dec;141 Suppl:219-28.

18. Wild S, Roglic G, Green A, Sicree R, King H. Global prevalence of diabetes : Estimates for the year 2000 and projections for 2030. Diab Care. 27:1047-1053, 2004

19. Yunir E, Waspadji S, Rahajeng E. The pre-diabetic epidemiological study in Depok, West Java. Acta Med Indones. 2009 Oct;41(4):181-5 